\title{
Islet amyloid polypeptide immunoreactivity in the human fetal pancreas
}

\author{
P.A.In 't Veld ${ }^{1}$, F.Zhang ${ }^{1}$, O.D.Madsen ${ }^{2}$ and G. Klöppel ${ }^{1}$ \\ ${ }^{1}$ Department of Pathology, Free University of Brussels (Jettes), Brussels, Belgium, and ${ }^{2}$ Hagedorn Research Laboratory, Gentofte, \\ Denmark
}

\begin{abstract}
Summary. Islet amyloid polypeptide is known to localize to the adult human Beta cell. We analysed the immunoreactivity for islet amyloid polypeptide in a series of 29 human fetal pancreata (9-24 weeks of gestation) with respect to age dependency and cellular localization using an antibody raised against synthetic rat islet amyloid polypeptide $12-37$. Cells immunoreactive for islet amyloid polypeptide were demonstrated in low numbers from week 13 onwards while insulin positivity was already present at 9 weeks of gestation. In the age group 13-16 gestational weeks, cells positive for insulin were 20 -fold more frequent than cells positive for islet amyloid polypeptide. This difference gradually disappeared with age, reaching parity in the adult gland. Double immunostaining demonstrated that all islet amyloid polypeptide immunoreactivity co-localized with insulin. Co-expression of in-
\end{abstract}

sulin and islet amyloid polypeptide was more frequent in Beta-cell clusters ( $\geq 10$ cells) than in single Beta cells; islet amyloid polypeptide positivity was present in $58 \pm 9 \%$ (mean $\pm \mathrm{SEM} ; n=4)$ of fetal, $88 \pm 9 \%(n=3)$ of neonatal and $100 \%(n=3)$ of adult clustered Beta cells, and only $8-18 \%$ of the single Beta cells. The results suggest that the developing fetal Beta cells, dependent on age and localization, differ in their capacity to express detectable amounts of immunoreactive islet amyloid polypeptide. Beta-cell maturation might therefore be associated with islet amyloid polypeptide expression.

Key words: Islet amyloid polypeptide, fetal pancreas, immunocytochemistry, distribution, age dependence.
Islet amyloid polypeptide (IAPP) is a 37 amino acid protein first isolated from a human insulinoma [1]. It is the main component of amyloid deposits found in the islets of Langerhans of patients with Type 2 (non-insulin-dependent) diabetes mellitus [2-4], and may therefore be involved in the pathogenesis of this type of diabetes [5]. In the normal adult pancreas it co-localizes with insulin in secretory granules $[6,7]$ from which it is released, together with insulin, in response to a glucose stimulus. This study examines at what stage of the development of the human pancreas IAPP can first be detected and whether it is present in all insulin-positive cells.

\section{Materials and methods}

\section{Tissue}

Bouin or formalin-fixed, paraffin embedded tissue was obtained from the Departments of Pathology of the Academic Hospitals of the Free University of Brussels (Jette), University of Zürich and University of Hamburg. The material included 29 normal fetal pancreata ranging from 9-24 weeks of gestation, three normal neonatal pancreata, and three adult donor pancreata. Fetal age was determined at the time of autopsy and was usually based on crown-rump measurement.

No distinction was made between the ontogenetically different lobes of the fetal and neonatal pancreas. The material from the adult donor pancreas was derived from the pancreatic-polypeptide-poor dorsal part.

\section{Immunoreagents}

Antibodies used in these studies included: rabbit anti-rat IAPP 12-37 [8]; mouse anti-insulin monoclonal antibody (MAB 3) (specifically directed against the B-30 amino acid residue of processed insulin; a gift from Dr. M.J.Storch, Albert-Ludwigs-Universität Freiburg, FRG [9]); mouse anti-insulin, OXI-002 (Novo Biolabs, Bagsvaerd, Denmark); mouse anti-glucagon, GLU-001 (Novo Biolabs); mouse anti-somatostatin SOM-018 (Novo Biolabs); biotinylated goat anti-rabbit IgG (Vector, Burlingame, Calif., USA); biotinlated horse anti-mouse IgG (Vector); goat anti-mouse fluorescin-isothiacianate (FITC)-conjugated IgG (Nordic Immunological Laboratories, Tilburg, The Netherlands); rat anti-mouse tetramethylrhodamine isothiocyanate (TRITC)-conjugated (Jackson, Westgrowe, Pa., USA) and streptavidin biotin complex (Dako, Glostrup, Denmark). 

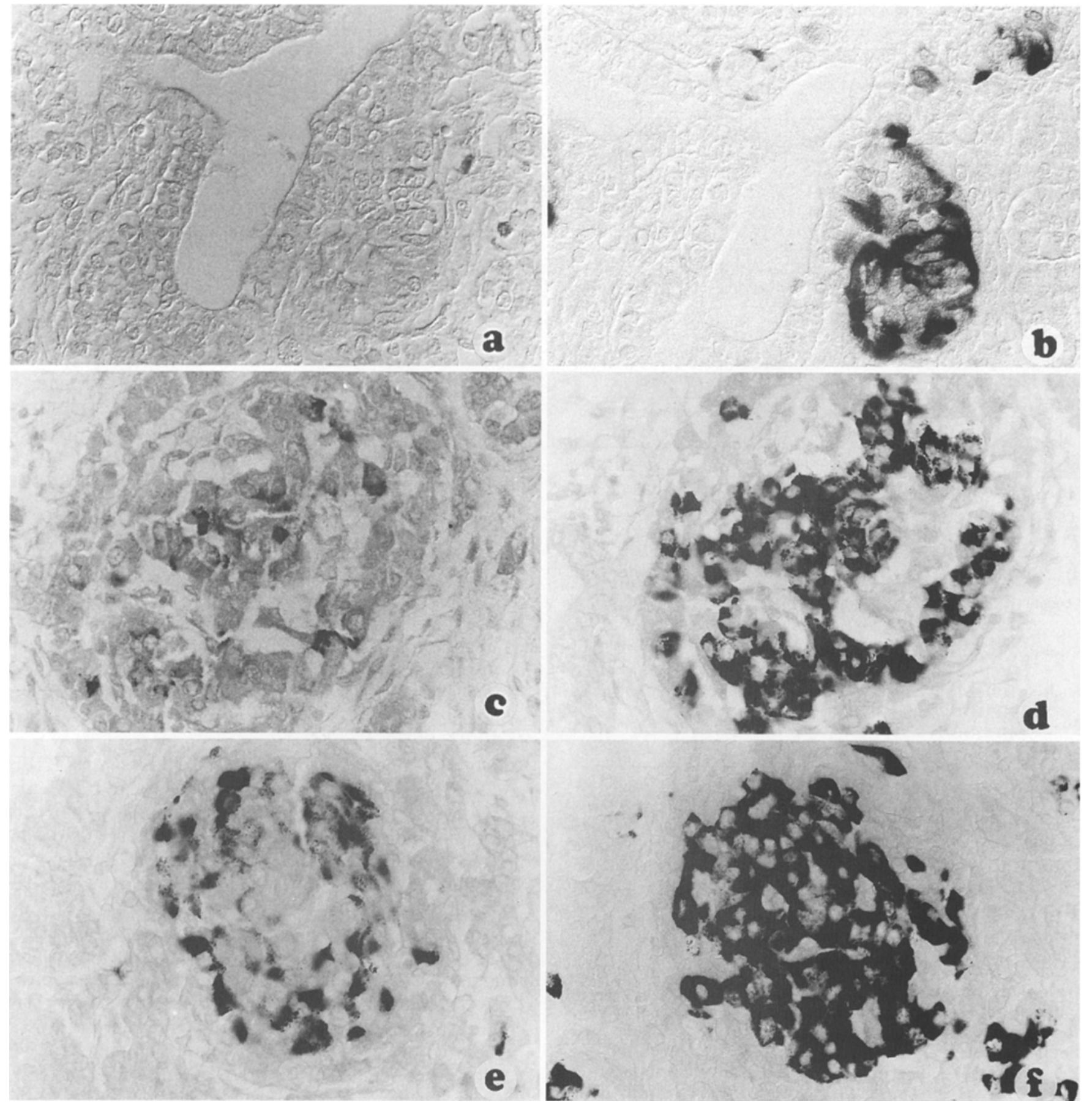

Fig. 1a-f. Immunocytochemical staining for islet amyloid polypeptide $(\mathbf{a}, \mathbf{c}, \mathbf{e})$ and insulin $(\mathbf{b}, \mathbf{d}, \mathbf{f})$ in consecutive sections of fetal human pancreas of 9 weeks $(\mathbf{a}, \mathbf{b}), 14$ weeks $(\mathbf{c}, \mathbf{d})$ and 24 weeks $(\mathbf{e}, \mathbf{f})$ gestational age (magnification $\times 700)$

\section{Immunoreactions}

Deparaffinized $5 \mu \mathrm{m}$ sections were treated with $3 \%$ hydrogen peroxide in methanol for $30 \mathrm{~min}$ to block endogenous peroxidase and incubated with $10 \%$ normal goat serum (Gibco, Madison, Wis., USA) in phosphate-buffered saline (PBS) $0.8 \%$ bovine serum albumin fraction V (Sigma Chemical Co., St.Louis, Mo., USA) to block non-specific binding. Sections were processed for either single label streptavidin-biotin-complex (ABC) staining, or double label immunofluorescence.

For $A B C$ staining, sections were incubated with either rabbit anti-IAPP $12-37$ or mouse anti-insulin MAB 3 overnight at $4^{\circ} \mathrm{C}$.
After treatment with the appropriate biotinylated second antibody, the streptavidin biotin complex and with $0.15 \%$ diaminobenzidine (Sigma), $0.3 \%$ hydrogen peroxide, $1 \%$ dimethyl sulphoxide in PBS, the staining product was intensified with $0.1 \%$ copper sulphate in PBS and sections were counterstained with Harris haematoxylin.

For double immunofluorescence labelling, sections were incubated with rabbit anti-IAPP 12-37 overnight at $4^{\circ} \mathrm{C}$, treated with a fluorescein-labelled second antibody, fixed with $2 \%$ paraformaldehyde, incubated with monoclonal antibodies against insulin (Novo), glucagon, or somatostatin for $3 \mathrm{~h}$, treated with a rhodamine-labelled second antibody, and mounted in a Tris-buffered glycerin / poly vinyl alcohol mixture $\mathrm{pH}$ 9.0. 
Table 1. Quantitation of islet amyloid polypeptide (IAPP) and insulin cells in the pancreas of different age groups

\begin{tabular}{|c|c|c|c|c|}
\hline $\begin{array}{l}\text { Age } \\
\text { (gestational } \\
\text { weeks) }\end{array}$ & $n$ & $\begin{array}{l}\text { number } \\
\text { of IAPP } \\
\text { cells }\end{array}$ & $\begin{array}{l}\text { number } \\
\text { of insulin } \\
\text { cells }\end{array}$ & $\begin{array}{l}\text { ratio } \\
\text { IAPP/ } \\
\text { insulin }\end{array}$ \\
\hline $9-12$ & 3 & 0 & $3.9 \pm 1.7$ & 0 \\
\hline $13-16$ & 8 & $0.8 \pm 0.8$ & $18.8 \pm 1.3$ & 0.04 \\
\hline $17-20$ & 11 & $4.9 \pm 1.4$ & $36.7 \pm 3.5$ & 0.13 \\
\hline $21-24$ & 7 & $8.5 \pm 2.2$ & $41.0 \pm 3.2$ & 0.21 \\
\hline neonatal & 3 & $26.6 \pm 7.4$ & $45.5 \pm 3.0$ & 0.58 \\
\hline adult & 3 & $15.5 \pm 2.0$ & $18.0 \pm 0.9$ & 0.86 \\
\hline
\end{tabular}

Data represent mean value \pm SEM of $n$ cases and are expressed as number of immunoreactive cells per microscopic field in consecutive sections stained for either insulin or IAPP

Table 2. Expression of islet amyloid polypeptide (IAPP)-like immunoreactivity in single and clustered Beta cells

\begin{tabular}{|c|c|c|c|c|c|c|}
\hline & \multirow[t]{2}{*}{ Case } & \multirow[t]{2}{*}{ Age } & \multicolumn{2}{|c|}{$\begin{array}{l}\text { Number of cells } \\
\text { analysed }\end{array}$} & \multicolumn{2}{|c|}{$\begin{array}{l}\% \text { of insulin cells } \\
\text { co-expressing IAPP }\end{array}$} \\
\hline & & & single & clustered & single & clustered \\
\hline \multirow[t]{5}{*}{ Fetal } & K53/80 & 19 weeks & 34 & 120 & 17.6 & 86.7 \\
\hline & MA23 & 23 weeks & 39 & 211 & 2.6 & 33.2 \\
\hline & 905 & 23 weeks & 49 & 220 & 6.1 & 39.1 \\
\hline & $\mathrm{K} 77 / 80$ & 24 weeks & 32 & 158 & 0 & 74.7 \\
\hline & & & & mean & $6.5 \pm 3.8$ & $58.4 \pm 13.1^{\mathrm{a}}$ \\
\hline \multirow[t]{4}{*}{ Neonatal } & $\mathrm{K} 136 / 80$ & 2.5 days & 63 & 303 & 14.2 & 70.0 \\
\hline & K18/80 & 7 days & 29 & 341 & 13.8 & 97.4 \\
\hline & K131/80 & 7 days & 69 & 251 & 11.6 & 96.0 \\
\hline & & & & mean & $13.2 \pm 0.8$ & $87.8 \pm 8.9^{\mathrm{a}}$ \\
\hline \multirow[t]{4}{*}{ Adult } & HP16DB & 19 years & 8 & 330 & 100 & 100 \\
\hline & HP11DB & 33 years & 4 & 296 & 100 & 100 \\
\hline & HP15DB & 46 years & 3 & 346 & 100 & 100 \\
\hline & & & & mean & $100 \pm 0$ & $100 \pm 0$ \\
\hline
\end{tabular}

Data are expressed as mean \pm SEM. The group of clustered Beta cells includes all insulin immunoreactive cells in aggregates of $\geq 10$ adhering cells. Significance of differences between single and clustered Beta cells within an age group were calculated using the Chi square test: ${ }^{\mathrm{a}} p<0.001$. Data are derived from a quantitative analysis of sections stained for both insulin and IAPP in a fluorescent double-labelling technique

The specificity of the staining reactions was tested by omitting the primary antibodies and replacing them with normal serum. In immunofluorescent double-labelling studies each of the four primary and secondary antibodies was deleted in turn to exclude crossbinding between the various antibody layers and to exclude potential signal cross-talking caused by inadequate separation of the emission wavelengths by the filter sets used. The specificity of the primary antibody against IAPP was tested by incubating the diluted antibody for $60 \mathrm{~min}$ with $10 \mu \mathrm{g} / \mathrm{ml}$ of one of the following peptides: rat IAPP 12-37 (a gift from Dr. H. Kofod, Hagedorn Research Laboratories, Gentofte, Denmark); porcine insulin (Nordisk, Gentofte, Denmark) and human calcitonin gene related peptide (Union Chemique, Braine l'Alleud, Belgium). No immunoreactivity was found after pre-absorption with IAPP. The reactivity pattern was not affected by pre-absorption with the other tested peptides.

\section{Quantitation}

ABC-stained sections were evaluated by counting the number of immunostained cells in photographic slides of randomly chosen microscopic fields (magnification $\times 100$; corresponding to an area of $0.077 \mathrm{~mm}^{2}$ ). A total of 4-18 microscopic fields (mean: $12.9 \pm 3.0$ ) were selected per section, depending on the size of the specimen.
The position of the selected areas over the section was randomly determined by a fixed meander pattern. The total number of immunopositive cells per section was divided by the number of fields analysed, resulting in the number of immunopositive cells per microscopic field.

Sections double-stained for the marker set insulin / IAPP were analysed by comparing two photographs, obtained in either FITC or TRITC excitation, of the same microscopic field at a final magnification of $\times 300$. A total of $5-13$ microscopicfields (mean: $9.3 \pm 2.5$ ) were evaluated per section, depending on the size of the specimen. The number of cells positive for IAPP was determined, and related as a percent to the number of cells per photograph positive for insulin.

\section{Results}

At 9-12 weeks of gestational age, the pancreatic tissue showed no IAPP-like immunoreactivity, but displayed insulin-positive cells (Fig.1 a, b; Table 1). IAPP immunoreactivity was first detected at 13 weeks of gestation. It was present in cells situated in the wall of ducts or scattered between acinar cells. After 14 weeks of gestation, a limited number of IAPP-positive cells was found in islet-like cell clusters (Fig.1c,d), and at 24 weeks of gestation, the IAPP-positive cells were predominantly present in the central part of the islets (Fig. 1 e,f). The number of IAPPpositive cells gradually increased with age from a mean of $0.8 \pm 0.8$ cells per high power microscopic field in the age group of 13-16 gestational weeks, to $26.6 \pm 7.4$ in the neonatal pancreas (Table 1 ). When compared to the number of insulin immunoreactive cells, the IAPP-positive cells occurred at a lower frequency in the fetal and neonatal age groups, and only reached near parity with the insulin cells in the adult group.

Double stainings for insulin / IAPP, glucagon / IAPP and somatostatin /IAPP were performed on four selected pancreata of 19 to 24 weeks of gestational age. It was found that IAPP immunoreactivity co-localized to insulin immunoreactive cells (Fig. 2a, b), but that no glucagon or somatostatin immunoreactive cells were convincingly labelled (Fig. $2 \mathrm{c}, \mathrm{d}, \mathrm{e}, \mathrm{f}$ ).

In order to determine whether IAPP was similarly expressed in single and clustered ( $\geq 10$ adhering and insulin immunoreactive) Beta cells, the number of insulin-positive cells co-expressing IAPP-like immunoreactivity was counted on double-stained sections and expressed as a percent of the total number of insulin immunoreactive cells in either a single or clustered configuration (Table 2). This analysis revealed that clustered Beta cells are 8.8-fold more frequently IAPP-positive than single Beta cells in the fetal stage (19-24 weeks), and 6.6-fold more frequently positive in the neonatal stage. Single Beta cells were rare in the adult gland, but the few cells encountered were all found to co-express IAPP. IAPP immunoreactive cells were always found to express insulin, indicating that in human tissue, both in the fetal, neonatal and adult stage, IAPP is a specific Beta-cell marker.

\section{Discussion}

In our series of 29 normal human fetal pancreata, IAPPlike immunoreactivity was first identified at 13 weeks of gestation. A similar result was obtained in a recent study 

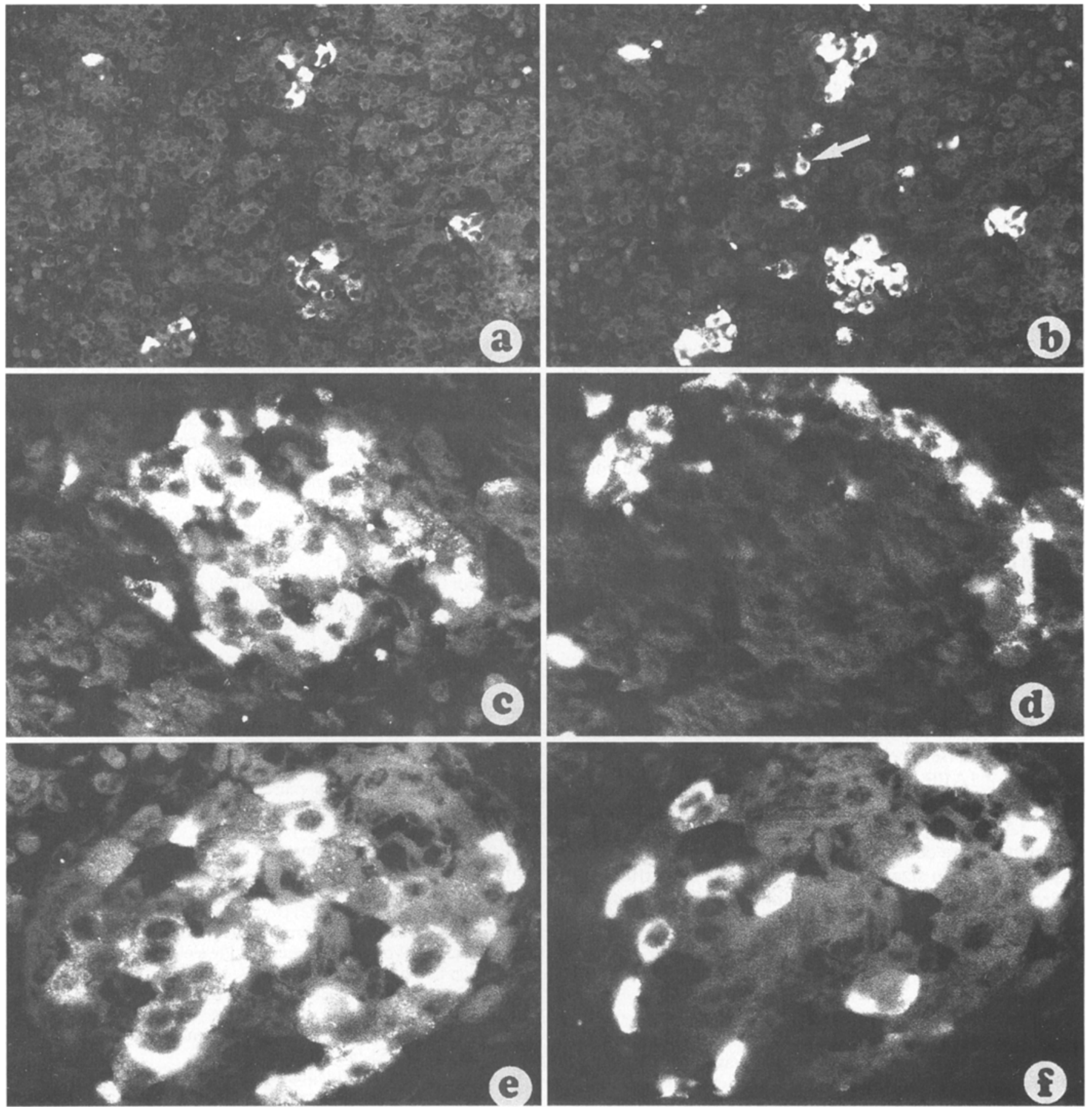

Fig. 2a-f. Immunofluorescent double-labelling for islet amyloid polypeptide (IAPP) (a) and insulin (b) in fetal human pancreas of 24 weeks gestational age (magnification $\times 300$ ) identifies single insulin-positive cells that lack co-expression of IAPP (arrow). Double-

labelling 19-week-old fetal human pancreas for IAPP (c,e) and somatostatin (d) or glucagon (f) does not identify cells that are convincingly positive for both markers (magnification $\times 1500$ )

by Rindi et al. [10] who also failed to detect IAPP immunoreactivity in 9-to-12-week-old pancreata but found IAPP positivity at 18 to 21 weeks of gestational age [10]. The IAPP expression at 13 weeks of gestation is considerably later than the expression of insulin which could already be detected as early as 9 weeks [10-12]. Using a double immunofluorescent labelling technique, we found that IAPP-like immunoreactivity was restricted to Beta cells, and was not demonstrable in Alpha or Delta cells.

This co-localization pattern could be found in the human fetal, neonatal as well as adult pancreas and confirms the staining pattern previously reported for the adult pancreas $[3,7]$. IAPP is therefore a specific marker for human endocrine Beta cells, which is in contrast to the situation in some rodents in which IAPP is expressed in cultured islet Delta cells [13].

In contrast to the adult pancreas where virtually all Beta cells co-expressed insulin and IAPP, the fetal pan- 
creas was found to contain a considerable percentage of insulin-positive cells that failed to stain for IAPP. These were especially identified among the single Beta cells, while the situation was reversed in Beta cells clustered in islets. The demonstration of insulin cells devoid of IAPP may possibly be explained by a different degree of granulation of these cells. As IAPP in the adult gland occurs in a $1: 30$ to $1: 500$ molar ratio with insulin [14], and is located in the insulin secretory granules [6], it is theoretically possible that IAPP can only be detected in insulin immunoreactive cells that contain a certain baseline amount of secretory granules. However, the similarly strong insulin immunoreactivity in single and clustered Beta cells makes this interpretation less likely. An alternative hypothesis therefore could be that the IAPP / insulin ratio may differ from cell to cell, and may also change during development. The fact that the proportion of IAPP-positive insulin cells significantly increased with gestational age and reached almost $100 \%$ in the adult pancreas, suggests that these changes are related to the development of the endocrine pancreas in general and the Beta cells in particular.

Although not much is known about Beta-cell ontogeny, it is generally assumed that islets develop from a limited number of precursor cells, that may either be Beta cells or pluripotent stem cells [15-17]. Whether this process involves aggregation of neighbouring single Beta cells, or repeated divisions of an initially single cell is unknown. Single Beta cells are much more frequent in the fetal and neonatal stages $[11,18]$, than in the adult organ. Their presence therefore may be interpreted as an early phase in fetal islet ontogeny. The absence of IAPP in most of these single Beta cells and the simultaneously strong expression of IAPP in Beta-cell clusters suggest a correlation between IAPP immunoreactivity and islet ontogeny. Thus, IAPP could be a marker for a sub-population of pancreatic Beta cells which appears at 13 weeks of gestation, increases in size with age and finally constitutes the entire Beta-cell population in adulthood. The functional significance of this sub-population is unclear, but the expression of IAPP-like immunoreactivity may possibly be a marker for an advanced stage of Beta-cell maturation.

Acknowledgements. The expert technical assistance of Ms. N.Buelens is gratefully acknowledged. This study was supported by grant 3.0093.90 of the Belgian Fund for Medical Scientific Research. We would like to thank Prof. Ph. U.Heitz and Prof. J. Briener, Department of Pathology, University of Zürich, for their assistance in obtaining some of the specimens, and Prof. Pipeleers for helpful discussions.

\section{References}

1. Westermark P, Wernstedt C, Wilander E, Sletten K (1986) A novel peptide in the calcitonin gene related peptide family as an amyloid fibril protein in the endocrine pancreas. Biochem Biophys Res Commun 140: 827-831

2. Cooper GJS, Willis AC, Clark A, Turner RC, Sim RB, Reid KB (1987) Purification and characterization of a peptide from amy- loid-rich pancreas of type 2 diabetic patients. Proc Natl Acad Sci USA 84: 8628-8632

3. Westermark P, Wilander E, Westermark GT, Johnson KH (1987) Islet amyloid polypeptide-like immunoreactivity in the islet $B$ cells of Type 2 (non-insulin-dependent) diabetic and nondiabetic individuals. Diabetologia 30: 887-892

4. Clark A, Saad MF, Nezzer T et al. (1990) Islet amyloid polypeptide in diabetic and non-diabetic Pima Indians. Diabetologia 33: 285-289

5. Porte D, Kahn SE (1989) Hyperproinsulinemia and amyloid in NIDDM: clues to etiology of islet $\beta$-cell dysfunction? Diabetes 38: $1333-1336$

6. Lukinius A, Wilander E, Westermark GT, Engström U, Westermark P (1989) Co-localization of islet amyloid polypeptide and insulin in the B cell secretory granules of the human pancreatic islet. Diabetologia 32: 240-244

7. Johnson KH, O'Brien TD, Hayden DW et al. (1988) Immunolocalization of islet amyloid polypeptide (IAPP) in pancreatic Beta cells by means of peroxidase-antiperioxidase (PAP) and protein A-gold technique. Am J Pathol 130: 1-8

8. Madsen OD, Nielsen JH, Petersen JS, Kofod H, Dyrberg T (1990) Expression of islet amyloid polypeptide and insulin in the pancreatic islet cells. In: Shafrir E (ed) Frontiers in diabetes research. Lessons from animal diabetes III, Smith-Gordon, London, pp 512-515

9. Storch MJ, Petersen KG, Licht T, Kerp L (1985) Recognition of human insulin and proinsulin by monoclonal antibodies. Diabetes 34: 808-811

10. Rindi G, Terenghi G, Westermark G et al. (1991) Islet amyloid polypeptide in proliferating pancreatic $B$ cells during development, hyperplasia, and neoplasia in humans and mice. Am J Pathol 138: 1321-1334

11. Clark A, Grant AM (1983) Quantitative morphology of endocrine cells in human fetal pancreas. Diabetologia $25: 31-35$

12. Stefan Y, Grasso S, Perrelet A, Orci L (1983) A quantitative immunofluorescent study of the endocrine cell populations in the developing human pancreas. Diabetes 32: 293-301

13. Madsen OD, Nielsen JH, Michelsen B et al. (1991) Islet amyloid polypeptide and insulin expression are controlled differently in primary and transformed islet cells. Molecular Endocrinology 5: 143-148

14. Nishi M, Sanke T, Nagamatsu S, Bell GI, Steiner DF (1990) Islet amyloid polypeptide, a new $\beta$ cell secretory product related to islet amyloid deposits. J Biol Chem 265: 4173-4176

15. Pictet R, Rutter WJ (1972) Development of the embryonic endocrine pancreas. In: Steiner DF, Freinkel N (eds) Handbook of physiology, Vol.1. The American Physiological Society, Bethesda, pp 25-66

16. Le Douarain NM (1988) On the origin of pancreatic endocrine cells. Cell 53: 169-171

17. Dubois PM (1989) Ontogeny of the endocrine pancreas. Hormone Res 32: 53-60

18. Rahier J, Wallon J, Henquin JC (1981) Cell populations in the endocrine pancreas of human neonates and infants. Diabetologia 20: $540-546$

Received: 9September 1991

and in revised form: 12 November 1991

Prof. G. Klöppel

Department of Pathology

Free University of Brussels

Campus Jette

Laarbeeklaan 103

B-1090 Brussels

Belgium 